\title{
Basidiomycetes at the timberline in Lapland 3. Two new boreal polypores with intricate hyphal systems
}

\author{
PERTTI RENVALL and TUOMO NIEMELÄ
}

\begin{abstract}
RENVALL, P. \& NIEMELÄ, T. 1992: Basidiomycetes at the timberline in Lapland 3. Two new boreal polypores with intricate hyphal systems. - Karstenia 32:29-42.

Two new saprotrophic polypore species, Antrodia primaeva Renvall \& Niemelä and $A$. infirma Renvall \& Niemelä (Basidiomycetes), are described. They have mostly been collected in northern Finland. Both are associated with brown rot and they have been found almost exclusively on old windfalls of Pinus sylvestris. A. primaeva resembles Dichomitus squalens (Karst.) Reid in having resupinate or effused-reflexed basidiocarps which are white to bay and soft when fresh. The overall structure of $A$. primaeva is trimitic; the tubes are dimitic, while the subiculum and cap context consist predominantly of generative hyphae, but contain skeletals and scattered binding hyphae close to the tube bottoms and sometimes next to the wood. Dichomitus squalens differs in having arboriform and cyanophilous skeleto-binding hyphae. A. primaeva is microscopically close to A. serialis (Fr.) Donk, but skeletal hyphae are dominant in the context of the latter and its whole structure is tougher. A. infirma is dimitic with very rare skeletal hyphae. A. oleracea (Davidson \& Lombard) Ryv. is similar to it, but has shorter basidiospores, shorter and almost pyriform basidia, smaller pores and different hosts. A. infirma is differentiated from Postia rancida (Bres.) Larsen \& Lombard and $P$. placenta (Fr.) Larsen \& Lombard by having true skeletals and longer, fusiform basidiospores. The vegetative hyphae of both the new species are unevenly distributed in the basidiocarp. Skeletal hyphae are often found in clusters in the trama, and horizontal sectioning is a useful method for examining their occurrence and distribution. The authors consider that the significance of the structure of hyphal system as one of the basic characters in the taxonomy of polypores requires some re-evaluation. In addition, a new polypore species, Dichomitus stenospora Renvall \& Niemelä, is described on the basis of North American material.
\end{abstract}

Key words: Antrodia infirma, Antrodia primaeva, Boreal, Dichomitus stenospora, Finland, hyphal system, polypores, primeval forest, taxonomy.

Pertti Renvall \& Tuomo Niemelä, Botanical Museum \& Department of Botany, University of Helsinki, Unioninkatu 44, SF-00170 Helsinki, Finland

\section{Introduction}

While studying our Nordic materials of resupinate polypores, we have come across certain clusters of species which share many general characters, but lack striking structures which would help the determination. One such group growing on conifers (see Antrodia sp. 1 in Renvall et al. 1991b) is characterized by thin, soft, resupinate fruit bodies, with light colours. The basidiospores are narrowly ellipsoid, approximating 6-8 $83 \mu \mathrm{m}$, and thick-walled hyphae are variably found in the inner structure. If such thickwalled hyphae are considered to be mere sclerified generative hyphae, the species approaches Postia placenta (Fr.) Larsen \& Lombard (Poria monticola Murr.). If stronger, hyphae of skeletal appearance were found, a probable identification was sought in the vicinity of Antrodia serialis (Fr.) Donk. However, these identifications to the 'nearest probable' name have left an uneasy feeling and a call for a closer study.

We here describe two new polypore species, $A n$ trodia primaeva Renvall \& Niemelä and $A$. infirma Renvall \& Niemelä, which were mostly collected in northern Finland. We also discuss the taxonomy of these new polypores and outline their distribution and ecology. We felt it necessary to compare them with Antrodia oleracea (Davidson \& Lombard) Ryv., Dichomitus squalens (Karst.) Reid, Postia placenta and many other related taxa, and to evaluate the importance of hyphal characters in separating the 
genera Antrodia Karst., Dichomitus Reid, Fibroporia Parm., Fomitopsis Karst., Pilatoporus Kotl. \& Pouz. and Rhodofomes Kotl. \& Pouz.

In addition, on the basis of the North American type material which we checked for this study, we formally describe a polypore earlier known as 'Poria stenospora Overh.'.

This is the third paper in a series devoted to the basidiomycetes at the timberline in Lapland, northern Finland. The background for the studies, the previous mycological literature, general geography, vegetation of the research area and nomenclature of the plants were treated in detail in an introductory paper (Renvall et al. 1991a). In the second paper (Renvall et al. 1991b) the polypores of northeastern Finland were listed and discussed.

\section{Materials and methods}

For the present paper we have studied 28 specimens of Antrodia primaeva and 12 specimens of A. infirma; most of those collections are our own. Additional specimens filed under Antrodia, Poria s. lat., Tyromyces s. lat., Dichomitus squalens and Postia placenta were checked in H, UPS, GB-J.E. and in some personal collections. For instance, 53 specimens of Dichomitus squalens (45 collections from northern Europe and 8 from North America) and 61 specimens of Postia placenta were studied in microscope. In addition, the types of the 14 additional species names were studied. They will be discussed more closely in the section Excluded taxa.

The material collected by us is mainly preserved in the Botanical Museum of the University of Helsinki $(\mathrm{H})$. Herbarium abbreviations are according to Holmgren et al. (1990). Other abbreviations: GB-J.E. $=$ the collections of the Department of Systematic Botany, University of Göteborg, established by Dr. John Eriksson. O-L.R. = the collections of the Biological Institute, University of Oslo, kept by Dr. Leif Ryvarden. Personal herbaria are abbreviated as follows: P.R. = Pertti Renvall, T.N. $=$ Tuomo Niemelä, H.K. = Heikki Kotiranta (all in Helsinki).

Microscopical characters were studied on each specimen with the microscopes Leitz Dialux 22 and Leitz Diaplan at magnifications up to $x 1250$. Anatomical details were drawn with the Leitz drawing tube. The chemical reagents used in the microscopical examination and their reactions are those listed by Niemelä (1985a, 1985b). We have used Cotton Blue $(\mathrm{CB})$ when drawing figures and when measuring the microscopical elements of basidiocarps. According to Parmasto \& I. Parmasto (1987) in general at least 30 spores from at least seven specimens should be measured to minimize statistically significant measure- ment errors when describing the variation of basidiospores of certain species. We have followed their recommendations and for both new Nordic species 30 basidiospores were measured from each of 10 specimens. In addition, a variable amount of spores were measured from other specimens. Premature and exceptionally large malformed spores were excluded from the measurements. In presenting the variation of the spore size, $5 \%$ of the measurements have been excluded from each end of the range, and are given in parentheses. In the text the following abbreviations are used: $\mathrm{L}=$ the mean spore length (arithmetical mean of all the spores), $\mathbb{W}=$ the mean spore width, $Q$ = quotient of the mean spore length and the mean spore width ( $\mathrm{L} / \overline{\mathrm{W}}$ ratio), $(\mathrm{n}=\mathrm{x} / \mathrm{y})=\mathrm{x}$ measurements of spores (basidia, basidioles, cystidioles, hyphae) from y specimens.

Spore shape terminology is very confusing, and in particular the word 'cylindrical' has many meanings. Truly cylindrical spores have parallel sides, so that the thickest part of the spore cannot be defined. If the thickest cross-section can be defined, i.e. the sides taper, even if slightly, towards the ends, proper terms would be elliptic, narrowly elliptic, subfusiform or fusiform. In this respect we follow the terminology of Largent et al. (1977).

In our opinion it is essential to study not only the tube wall structure, but also the make-up of the subiculum or pileal context, as seen in thin, vertical, radial sections extending from the very attachment to the wood, down to the transitional zone adjoining the tubes. In some cases special hyphal types are seen adjacent to the substrate only, or in cavities of decaying wood beneath the basidiocarp. We have also used horizontal sectioning of the trama (Fig. 9) in examining the hyphal system in the microscope. We find it a useful method of clarifying the distribution of generative vs. skeletal hyphae in both the species of Antrodia described here.

The collecting (see Renvall et al. 1991b), herbarium studies, microscopical examination and measurements were mostly done by P.R. This article was written by him, too, although the authors collaborated on the taxonomical discussions. The figures of anatomical details have been drawn by T.N. and the BW photographs are by him, while the colour photos and the maps are by P.R.

\section{Antrodia primaeva Renvall \& Niemelä n.sp.}

Carpophorum annuum, effusum vel effuso-reflexum. Systema hypharum trimiticum, contextus hyphis generativis fibulatis numerosis, hyphis skeletalibus et ligativis sparsis; trama dissepimenti dimiticum. Sporae (6-)6.2-9(-11) x (2.3-)2.5-3.3(-3.8) $\mu \mathrm{m}$. 

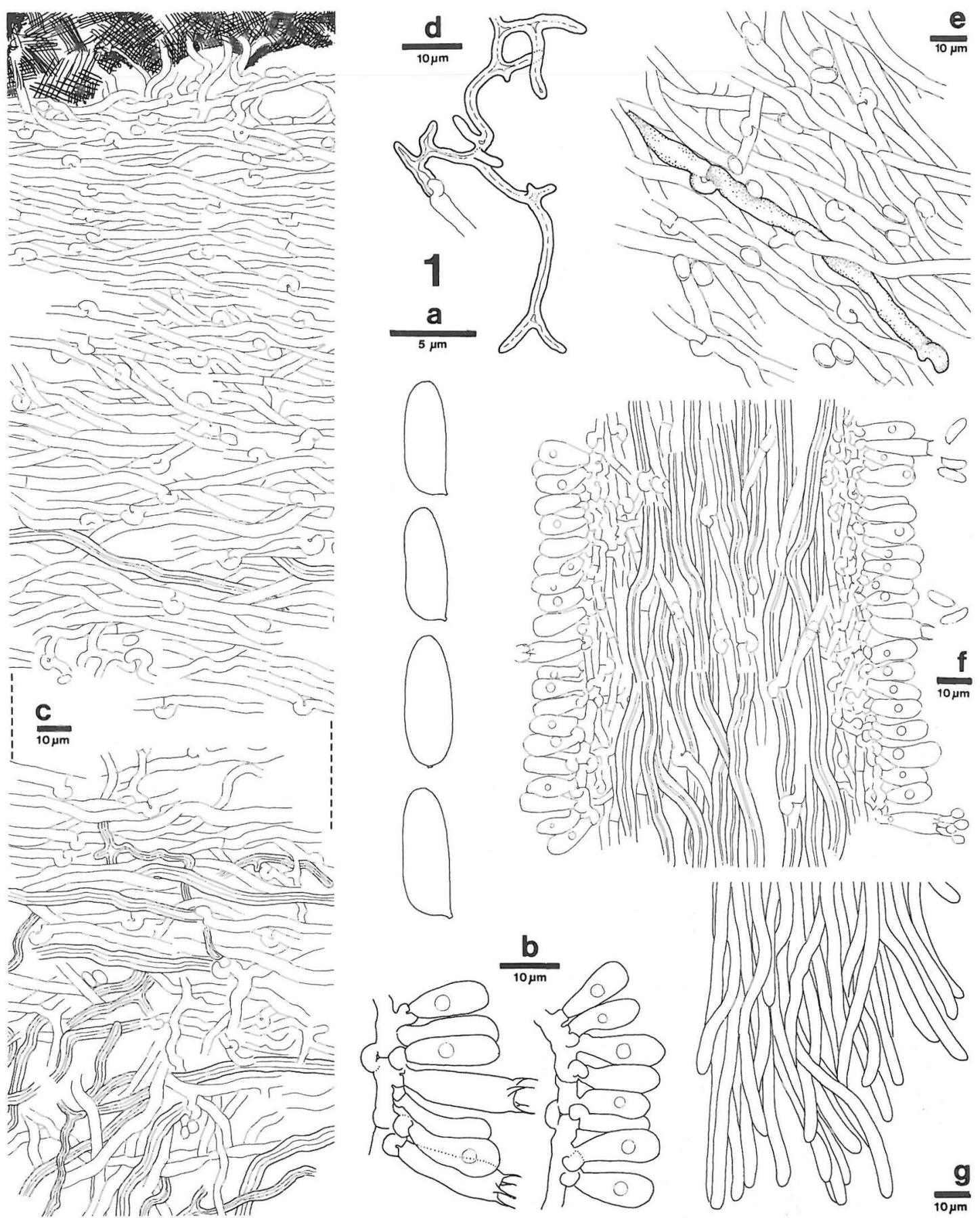

Fig. 1. Anatomical details of Antrodia primaeva Renvall \& Niemelä: a) basidiospores, b) basidia and basidioles, c) a section through subiculum showing a basal layer against wood (upper part) and transitional hyphae near dissepiments (lower part), d) a contextual binding hypha, e) contextual generative hyphae with a gloeoplerous hypha, f) a section through upper dissepiment, g) dissepiment edge in a vertical section. Drawn in Cotton Blue. Figures a, d, e from the holotype (H); b, f from Renvall 991 (H); c, $g$ from Kotiranta $6936(\mathrm{H})$. 

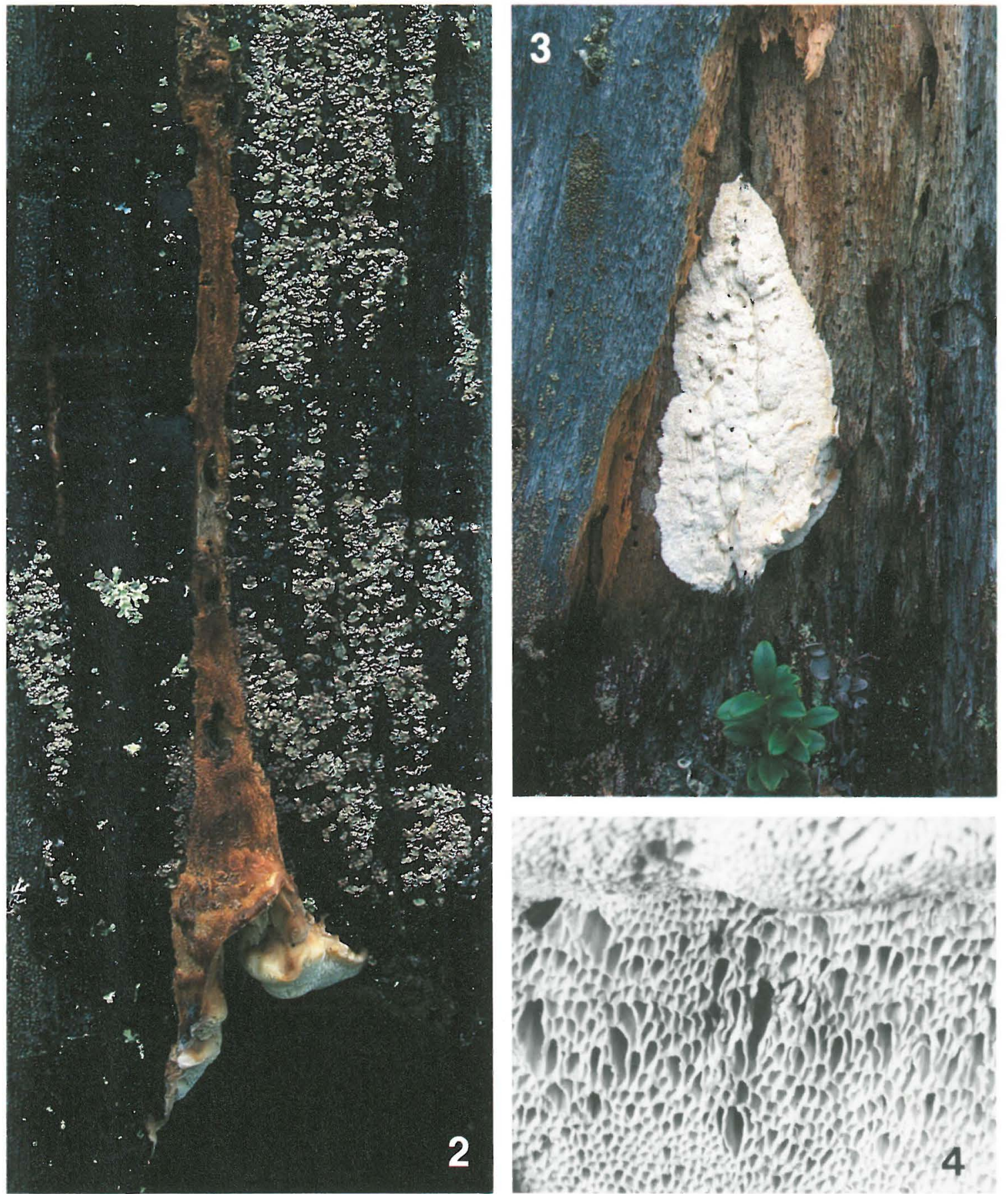

Figs. 2-4. Antrodia primaeva Renvall \& Niemelä. - 2: A fresh, pileate basidiocarp, photographed in situ, $x$ 1. Renvall 972, (H). 3: Mostly resupinate basidiocarp, fresh, x 0.6. Renvall $1112(\mathrm{H})$. - 4: Pore surface, $x$ 6. Herbarium specimen, holotype (H). 
Holotypus: Finland. Sompion Lappi, Savukoski, Urho Kekkonen National Park, fallen trunk of Pinus sylvestris, 19.IX.1988 P. Renvall 1372 \& T. Renvall (H, effused-reflexed stage, isotypi in DAOM and $\mathrm{O}$ )

Basidiocarps annual, resupinate or effused-reflexed, soft, succulent and cheese-like when fresh, shrinking upon drying and brittle to fairly hard when dry, resupinate areas $(1-) 3-10(-20) \times 1-5(-10) \mathrm{cm}$ wide and up to $15 \mathrm{~mm}$ thick at centre. Pilei, if present, bluntly triquetrous, up to $7 \mathrm{~cm}$ wide, projecting $0.5-$ $1.5 \mathrm{~cm}$ from substrate, $1-2 \mathrm{~cm}$ thick at the base, always attached to effused parts. Upper surface cream-coloured to unevenly pale brown or bay, evidently discolouring with age from the base outwards, first matted or finely tomentose, later more glabrous, azonate, in dry condition radially slightly wrinkled and with warts (Figs. 2 and 3). Sterile margin usually distinct in resupinate parts, $0.5-1 \mathrm{~mm}$ wide and thin, felty or finely radially fibrose, white to bay, when dry usually paler than the pores. Pore surface when young and fresh white to cream-coloured, with age and when dry becoming yellowish or widely discoloured with light brown to woody colours; pores angular, (1-)2-4 per $\mathrm{mm}$, when dry walls fairly thin, $0.04-0.06 \mathrm{~mm}$ thick; tube mouths (Fig. 4) under lens ( $x$ 50) compactly matted, even or when old lacerate (dry). Section: Context white to cream with a brownish tint, in subiculum $0.5-5 \mathrm{~mm}$, in pilei up to $15 \mathrm{~mm}$ thick, soft when fresh, when dry soft-corky and brittle when cut, in pileate basidiocarps often with very thin brown lines near the upper surface; a thin brown cuticle often seen in a section. Tubes concolorous with pore surface or when dry usually paler, up to $14 \mathrm{~mm}$ long.

Hyphal system trimitic (but appearing dimitic), all hyphae inamyloid, indextrinoid, acyanophilous and non-metachromatic. Context: Trimitic (but appearing monomitic), generative hyphae predominating in most parts, always thin-walled, rarely branched but with frequent cross-walls and clamp connections, $2.2-6 \mu \mathrm{m}$ wide $(n=115 / 10)$, often with oily contents, a few of them gloeoplerous (Fig. 1e), slightly radially oriented in pilei and horizontally subparallel in resupinate parts and then with indistinct basal layer (Fig. $1 c)$; skeletals winding, otherwise as in trama, in context rare, but locally fairly abundant just above tubes; binding hyphae (Fig. 1d) thick-walled, 1.5-3.8 $\mu \mathrm{m}$ wide $(n=63 / 10)$, with rather frequent and short branches, present close to tube bottoms and especially in very restricted patches at pileal base next to substrate. Tubes: Trama dimitic (Fig. 1f), generative hyphae abundant, subparallel, 1.8-4 $\mu \mathrm{m}$ wide $(\mathrm{n}=$ 119/13), thin-walled, otherwise as in context; skeletal hyphae predominating, parallel and fairly straight, refractive, thick-walled to subsolid and with oily contents (character seen especially well in $\mathrm{KOH}$ ),
2.5-5 $\mu \mathrm{m}$ wide ( $\mathrm{n}=212 / 15)$; no binding hyphae in tube trama. Subhymenium fairly distinct. Hymenial cells attached together in a honeycomb structure (best seen in areas where hymenium has flattened). Basidioles clavate, stout-based, 13-20 $\times 4.5-7 \mu \mathrm{m}(\mathrm{n}=30 /$ 2 ), often with single refractive droplets (Fig. 1b). Basidia clavate, with a basal clamp, sometimes strongly bent and arising deep within the subhymenium, with four sterigmata, $15-23 \times 4.5-8 \mu \mathrm{m}(\mathrm{n}=43$ / 7). Cystidia absent but apiculate cystidioles (thinwalled, basidiole-sized) sometimes present, rare. $\mathrm{Ba}$ sidiospores (Fig. 1a) very narrowly ellipsoid and when mature with a subfusiform distal end, sometimes more ellipsoid (young), fairly thin-walled, smooth, inamyloid, indextrinoid and acyanophilous, (6-)6.2-9(-11) x (2.3-)2.5-3.3(-3.8) $\mu \mathrm{m}, \overline{\mathrm{L}}=7.37$, $\overline{\mathrm{W}}=2.95, \mathrm{Q}=2.30-2.68(\mathrm{n}=334 / 15)$.

Etymology: primaevus (Lat., adj.), referring to primeval forest which has never felt the axe.

\section{Distribution and ecology}

\section{Specimens examined.}

Finland. Kainuu: Vuolijoki, Pinus sylvestris, 1991 Airaksinen (H). Koillismaa: Kuusamo, Oulanka Nat. Park, P. sylvestris, 1979 Niemelä 1592 (T.N.). Salla, Värriö Strict Nat. Res., $P$. sylvestris, 1988 P. Renvall 972, 987, 989 (H), 991 (P.R., O-L.R.), 1000 (P.R.), 1007, 1046, 1059a, 1061, 1068, 1111, 1112 (H), T. Renvall 316 (H, O-L.R.), 345, 399 (H), 1991 P. Renvall 2536, 2567, 2596 (H). Sompion Lappi: Savukoski, Urho Kekkonen Nat. Park, P. sylvestris, 1988 P. Renvall 1356a (H), 1372 (holotype, H, isotypes DAOM, O). Enontekiön Lappi: Enontekiö, Pallas-Ounas Nat. Park, Vuontisjärvi, P. sylvestris, 1980 Niemelä 2154 (H), 2162 (T.N.), Kotiranta 2315 (H). Inarin Lappi: Inari, Kessijärvi, P. sylvestris, 1988 Kotiranta 6936 (H.K.).

Norway. Finnmark: Sør-Varanger, near the border junction of Norway, Russia and Finland, P. sylvestris, 1969 Ryvarden (J.Eriksson 7423, GB-J.E.).

Sweden. Lule Lappmark: Jokkmokk, Ananas, inside old house, 1953 Eriksson 3709 \& Olsson (GB-J.E.). Torne Lappmark: Jukkasjärvi, Abisko Nat. Park, P. sylvestris, 1976 Sunhede (J.Eriksson 21093, GB-J.E.).

The distribution of Antrodia primaeva (Fig. 5) falls in the Northern Boreal zone as delimited by Ahti et al. (1968; map also in Koski-Kotiranta \& Niemelä 1988). Although there is one collection from the Middle Boreal zone, that locality also lies near the border of the Northern Boreal zone. The species seems to be commonest close to the timberline. Thus, the distributional pattern is strictly or strongly boreocontinental, as defined by us (Renvall et al. 1991b), and it may be similar to that of Laurilia sulcata (Burt) Pouz. (see Eriksson \& Strid 1969, Ryvarden 1971) or Peniophora septentrionalis Laurila (see Kotiranta \& Larsson 1990). We therefore expect this species to be found elsewhere in Scandinavia in old forests on high 


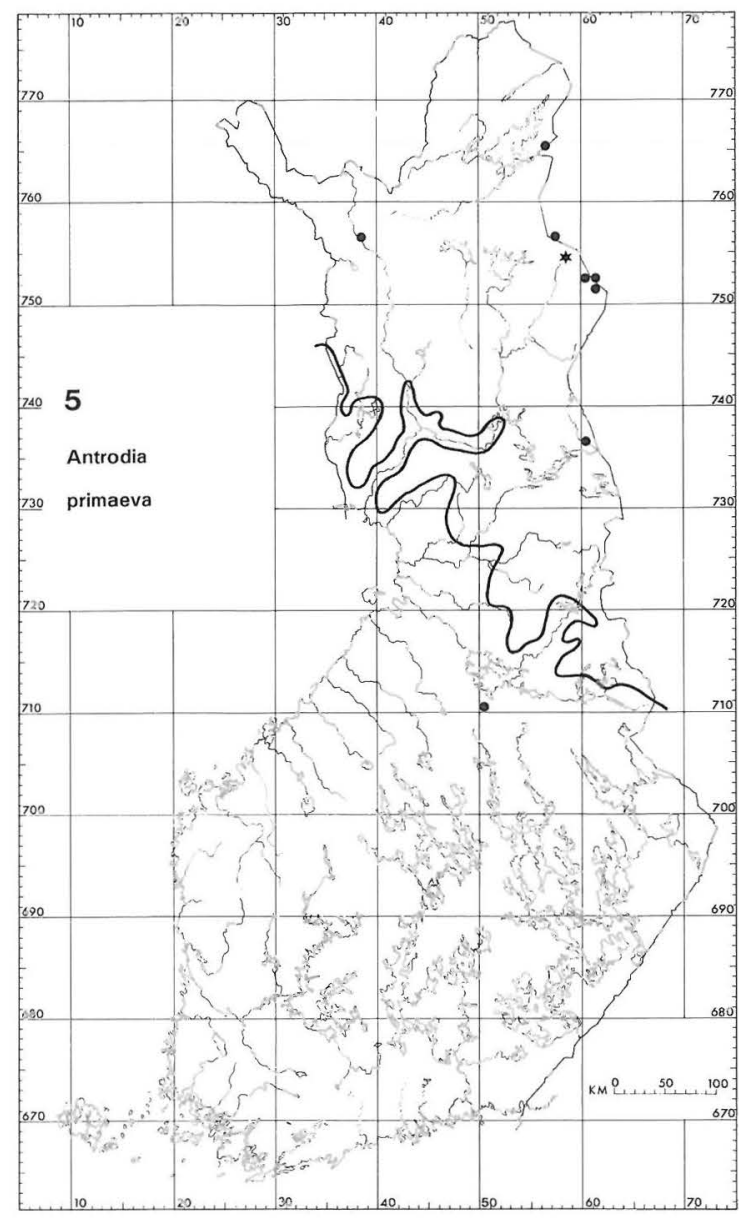

Fig. 5. The distribution of Antrodia primaeva Renvall \& Niemelä in Finland according to the material examined. * = The type locality.

mountains and in the Northern Boreal zone of Russia, and perhaps also at high altitudes in the upper montane coniferous (Oroboreal) zone of Central and South Europe.

The habitat ecology of Antrodia primaeva is characteristic. In Finland the species has been found almost exclusively in rather dry virgin pine forests, on fallen trunks or on natural stumps of Pinus sylvestris. Of the collections from eastern Finnish Lapland $(\mathrm{n}=$ 21), $86 \%$ are from forests of the Empetrum-Myrtillus site type and two specimens were collected in the drier Uliginosum-Vaccinium-Empetrum type. The main forest site types of that area were described in detail by Renvall et al. (1991a). A few finds derive from dry, spaced spruce woodlands intermixed with old emergent pines. A. primaeva is evidently a sapro- trophic fungus, which causes a slowly proceeding brown rot and favours fairly big fallen trunks. Of the collections $(n=28) 36 \%$ are from charred wood, which indicates a high resistance to drought, and perhaps an adaptation to forest fires. The basidiocarps mostly emerge on decorticated wood, growing out of deep fissures. Many finds were made on pines over one hundred years old, which had died and lost their bark but remained standing for decades before falling down. Such trees are characteristic of the North and are becoming more and more rare. The species grows mostly alone: in eastern Finnish Lapland it was noted growing on the same trunk or stump with an associate wood-rotting fungus only six times (out of 20 ). In view of these observations on its ecology, we consider it a threatened species and we propose that it should be included in the Red Lists of fungi in the Fennoscandian countries.

The fact that this species has escaped the attention of mycologists for so long must be due to the strong yearly variation in fruit body emergence. During periods of intensive field work in 1987, 1988, 1989 (Renvall et al. 1991a) and 1991 in eastern Finnish Lapland, the species was found only in 1988, when there was an exceptionally good growing season for fungi, and in 1991. In 1989 it was not found at all, although it was searched for carefully in the known localities, and in 1991 only old basidiocarps were found.

\section{Notes on Antrodia primaeva}

In the herbarium material that we have checked for this study Antrodia primaeva was filed three times under Dichomitus squalens and once under each of the following taxa: Diplomitoporus flavescens (Bres.) Dom., Antrodia albobrunnea (Rom.) Ryv. and Postia placenta. Antrodia primaeva is macroscopically similar to Dichomitus squalens in its white to bay and effused-reflexed basidiocarps, and the similarity is emphasized by the brown colours of the pileus (Fig. 2). In the microscope, however, it is seen to differ from $D$. squalens in its hyphal characters: the trama is predominantly composed of straight, thick-walled, acyanophilous true skeletal hyphae and richly clamped, thin-walled generative hyphae (Fig. 1f), while $D$. squalens always has arboriform and cyanophilous (reaction clear but weak, becoming stronger after a few hours) skeleto-binding (skeleto-ligative) hyphae, which predominate in both the trama and context (see e.g. Gilbertson \& Ryvarden 1986, Fig. 110). The tramal characters of the new species are closer to those of Antrodia serialis which, however, has tough and almost homogeneous, dimitic context, in which 
skeletal hyphae predominate, while the context of $A$. primaeva is almost monomitic and chiefly composed of richly clamped thin-walled generative hyphae, though some true binding hyphae (in the sense of Corner 1953) are always present and a few skeletals (Fig. 1c-e). The binding hyphae often occur at or near the attachment to the wood and in the transitional zone just above the tube bottoms. The skeletal hyphae in the trama are thinner and more interwoven in $A$. serialis than in A. primaeva. Diplomitoporus flavescens has a yellowish pore surface and slightly bent shorter basidiospores, and it causes a white rot (for descriptions see, e.g., Domański 1970b, 1972). Microscopically, Antrodia primaeva is reminiscent of some species of Fomitopsis. F. palustris (Berk. \& Curt.) Gilb. \& Ryv. (Pilatoporus palustris (Berk. \& Curt.) Kotl. \& Pouz.) has similar basidiospores and is reported to be dimitic (Gilbertson \& Ryvarden 1986). $F$. iberica Melo \& Ryv. also has similar microscopic characters (Melo \& Ryvarden 1989). However, Antrodia primaeva is clearly separated from these taxa by its annual, soft, cheese-like basidiocarps, almost monomitic context with only a few binding hyphae and dimitic trama.

In fresh condition Antrodia primaeva can be identified by its white to unevenly pale brown, soft, juicy basidiocarps (Figs. 2 and 3) and by its occurrence exclusively on pine, but it is easily mistaken for some species of Postia (Oligoporus), mainly Postia leucomallella (Murr.) Jül. Its basidiospores are different, however, and the dimitic trama and almost monomitic context with some true binding hyphae make it a distinct species and identifiable in the microscope.

\section{Antrodia infirma Renvall \& Niemelä n.sp.}

Carpophorum annuum, effusum; pori angulati (1-)3-4 per mm. Systema hypharum dimiticum, hyphae generativae fibulatae, abundantes et in contexto et in trama; hyphae skeletales rarissimae. Sporae (6-)6.3-8.5(-10.1) x (2-)2.2-3(-3.4) $\mu \mathrm{m}$, ad apicem distalem subfusoideae.

Holotypus: Finland. Pohjois-Karjala, Lieksa, Patvinsuo National Park, Autiovaara, fallen trunk of Pinus sylvestris, 14.IX. 1989 R. Penttilä 1235 (H, isotypi in DAOM, O and O-L.R.).

Basidiocarps annual, resupinate, $2-10(-15) \times 0.5-$ $5(-10) \mathrm{cm}$ wide, soft when fresh, somewhat brittle when dry. Margin white to bay, when dry paler than mature pores, sterile edge only ca. $0.5 \mathrm{~mm}$ wide and pubescent, pores usually extending to the very margin. Pore surface when young and fresh pure white, changing to distinctly cream, straw, yellowish or wood-coloured upon drying; pores angular, (1-)3-4 per $\mathrm{mm}$, intermixed with scattered larger ones (Fig. 7), walls very thin and papery, ca. $0.02 \mathrm{~mm}$ thick (dry); tube mouths under lens ( $x$ 50) even or faintly serrate. Section: Subiculum white and very thin, $0.2-1$ $\mathrm{mm}$ thick, tubes up to $3 \mathrm{~mm}$ long, about the same colour as the subiculum.

Hyphal system dimitic (but appearing monomitic), all hyphae inamyloid, indextrinoid, acyanophilous and non-metachromatic. Subiculum: Dimitic (Fig. 6f) (but appearing monomitic), generative hyphae predominating in all parts, delicately thinwalled, occasionally branched and with frequent cross-walls and clamp connections, $1.9-4.8 \mu \mathrm{m}$ wide ( $n=113 / 9$ ), often with oily contents (character seen especially well in $\mathrm{KOH}$ ), a few of them gloeoplerous, sclerified generative hyphae (reminiscent of binding hyphae, Fig. 6c) often present inside insect cavities or pockets of rot in wood, moderately branched, thickwalled, repeatedly clamped, rare to fairly abundant; skeletals extremely rare, but locally just above tubes some hyphae usually present, somewhat winding, otherwise as in trama. Tubes: Trama dimitic (Fig. 6d) (but appearing monomitic), generative hyphae dominant in all parts, interwoven to subparallel, 1.8-3.9 $\mu \mathrm{m}$ wide $(\mathrm{n}=106 / 9)$, otherwise as in context; skeletal hyphae rare to occasional, often irregularly distributed in clusters (Fig. 9b) and sometimes difficult to find but always easy to identify, found most easily in upper parts of tubes, but may reach down to dissepiment edges, fairly straight to winding, refractive, thick-walled but with a distinct lumen, $2.4-5 \mu \mathrm{m}$ wide ( $n=67 / 8$ ) and often with oily contents. Subhymenium indistinct. Hymenial cells glued firmly together into a honeycomb structure (best seen in areas where hymenium has flattened) and difficult to separate in $\mathrm{CB}$, in $\mathrm{KOH}$ easier to squash. Basidioles clavate, slenderbased, $15-22 \times 3.8-6.5 \mu \mathrm{m}(\mathrm{n}=30 / 2)$ (Fig. 6b). Basidia clavate, with a basal clamp and with four sterigmata, $16-22 \times 4-8 \mu \mathrm{m}(\mathrm{n}=46 / 5)$. Cystidia absent but thin-walled cystidioles (Fig. 6b) usually present, with a short or finger-like apex, 19-29 × 3-5 $\mu \mathrm{m}(n=14 / 6)$. Basidiospores very narrowly ellipsoid and when mature mostly with a fusiform distal end, slightly bent outwards (Fig. 6a), fairly thin-walled, smooth, inamyloid, indextrinoid and acyanophilous (6-)6.3-8.5(-10.1) x (2-)2.2-3(-3.4) $\mu \mathrm{m}, \bar{L}=7.33$, $\check{\mathrm{W}}=2.65, \mathrm{Q}=2.45-3.12(\mathrm{n}=305 / 10)$.

Etymology: infirmum (Lat., adj.), not firm, in contrast to most Antrodia species, whose abundant skeletal hyphae make them tough.

\section{Distribution and ecology}

\section{Specimens examined}

Finland. Satakunta: Ikaalinen, Seitseminen Nat. Park, Pinus sylvestris, 1986 Penttilä $364(\mathrm{H})$. Etelä-Häme: Asikkala, Kop- 


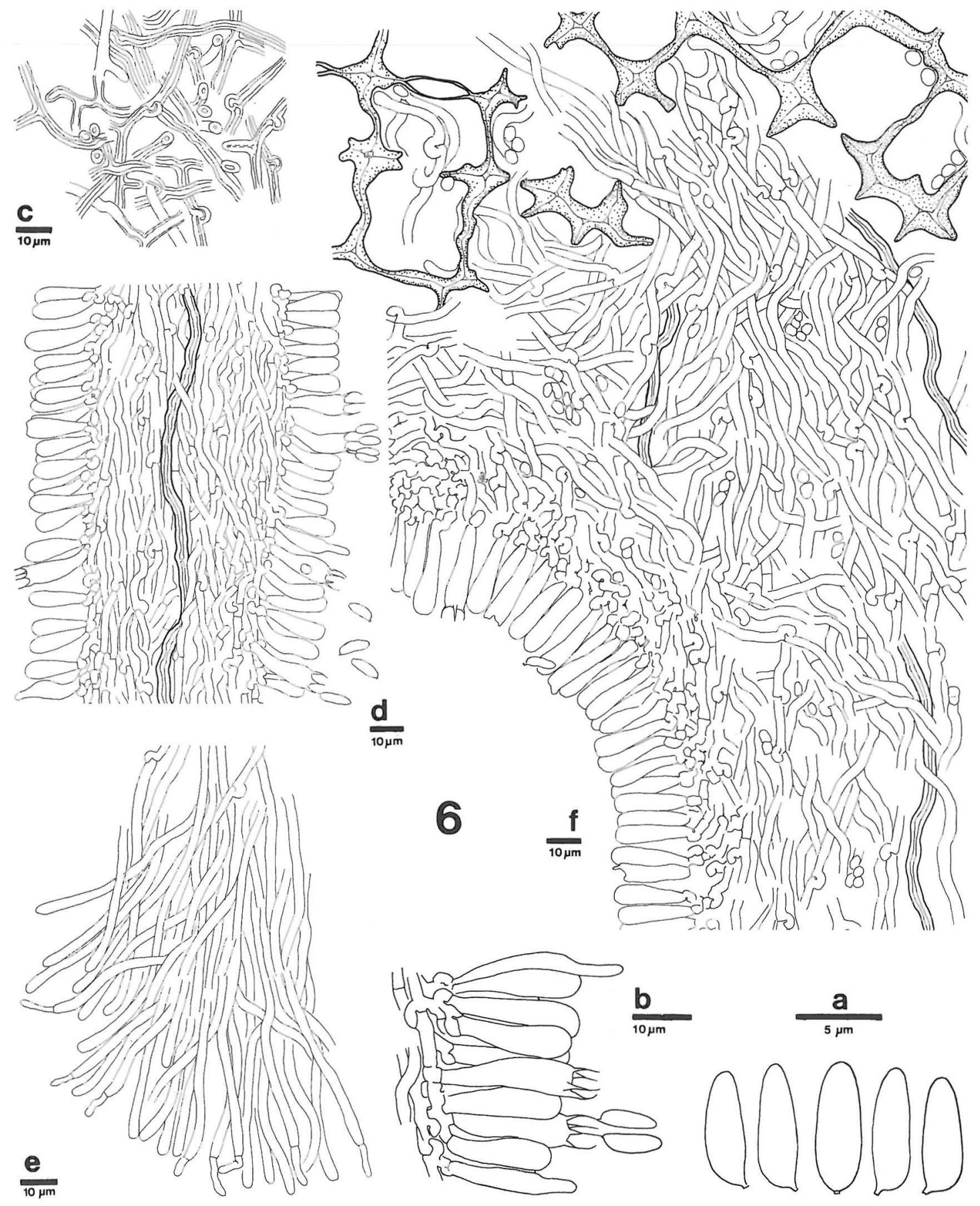

Fig. 6. Anatomical details of Antrodia infirma Renvall \& Niemelä: a) basidiospores, b) basidia and basidioles, c) sclerificd generative hyphae from an insect cavity inside wood, d) dissepiment edge, e) a section through subiculum and upper dissepiment. Drawn in Cotton Blue. Figures a, c, d, f from Renvall $1144(\mathrm{H}) ; \mathrm{b}$, e from the holotype $(\mathrm{H})$. 
suo, on a wall log of an old barn ( $P$. sylvestris?), 1980 Haikonen 590 (H). Lammi, Evo, $P$. sylvestris, 1980 Niemelä $2262(\mathrm{H})$. Pohjois-Karjala: Lieksa, Patvinsuo Nat. Park, P. sylvestris, 1989 Penttilä 1235 (holotype H, isotypes DAOM, O, O-L.R.), 1404, $1441(\mathrm{H})$. Pielisjärvi, Koli, Picea abies, 1979 Niemelä 1663 \& Kotiranta (T.N.). Kainuu: Vuolijoki, Pinus sylvestris, 1991 Airaksinen (H). Perä-Pohjanmaa: Tervola, Pisavaara Strict Nat. Res., P. sylvestris, 1979 Niemelä 1533 \& Kotiranta (T.N.). Koillismaa: Salla, Värriö Strict Nat. Res., P. sylvestris, 1991 P. Renvall 2601 (P.R.). Sompion Lappi: Savukoski, Värriö Strict Nat. Res., P. sylvestris, 1988 P. Renvall 1144 (H, O-L.R.). Savukoski, Urho Kekkonen Nat. Park, Jaurujoki, $P$. sylvestris, 1988 T. Renvall $414(\mathrm{H})$.

Little can be said about the total distribution of Antrodia infirma. According to our material, it is a rare boreal species with a scattered occurrence, being restricted to virgin or old forests. It has not been found in southern or western parts of Finland (Fig. 8). The northwesterly distribution may merely be a consequence of the rarity of virgin forests in the western part of the country, or it may reflect the climatic tolerance of the species. A. infirma has been found almost exclusively on naturally fallen trunks of conifers, mainly Pinus sylvestris and it is a saprotrophic fungus, which seems to cause a slowly proceeding brown rot. Most of the collections derive from decorticated, large and fairly strongly decayed trunks, which indicates a preference or need of stable conditions.

Due to this fairly exacting growth site ecology, we feel that Antrodia infirma should be included in the list of threatened fungi in Finland. The pattern of very isolated occurrences (Fig. 8) increases the vulnerability of the species.

\section{Notes on Antrodia infirma}

Antrodia infirma is close to Antrodia oleracea, Fibroporia mappa (Overh. \& Lowe) Niemelä (Postia mappa (Overh. \& Lowe) Larsen \& Lombard), Postia rancida (Bres.) Larsen \& Lombard (Oligoporus rancidus (Bres.) Gilb. \& Ryv.) and Postia placenta. It differs from the two last-mentioned polypores in having true skeletals and longer, very narrowly ellipsoid basidiospores, whose fusiform distal end is especially characteristic. $P$. rancida and $P$. placenta are both monomitic and their basidiospores are slightly curved, tapering more or less clearly towards the apiculus (proximal end), but being rounded at their distal ends. Unlike Antrodia oleracea, Postia rancida and $P$. placenta, Antrodia infirma exudes a coagulating substance in $\mathrm{KOH}$, which soon gives the mount characteristically messy appearance. A description of $P$. rancida can be found, for instance, in Gilbertson and Ryvarden (1987). The variability of Postia placenta has been discussed in detail by Domański

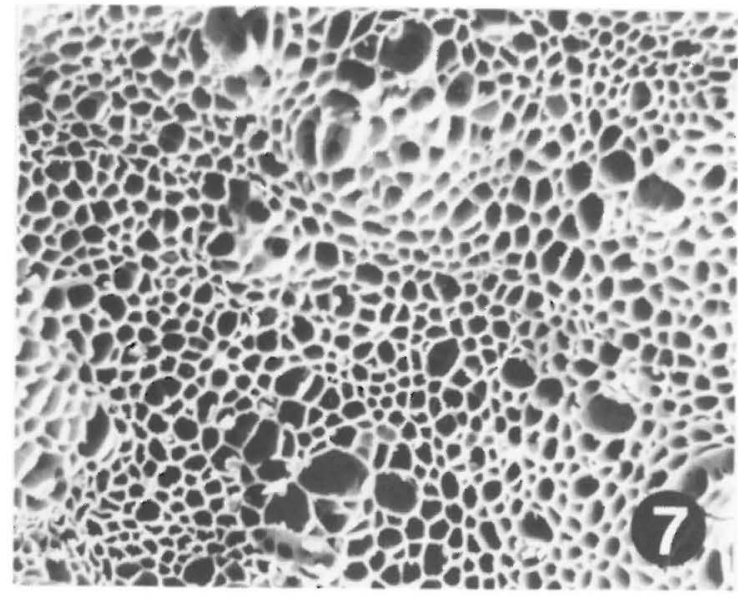

Fig. 7. Pore surface of Antrodia infirma Renvall \& Niemelä, $x 6$. Herbarium specimen, holotype $(\mathrm{H})$.

(1965, 1970a, 1972 as Ceriporiopsis placenta) and good descriptions are presented by Eriksson (1958), and Gilbertson and Ryvarden (1987, as Oligoporus placentus). Fibroporia mappa differs from the new species in having longer, rod-shaped, cylindrical basidiospores and a monomitic trama. F. mappa has been discussed and illustrated by Niemelä (1985b).

Antrodia oleracea shares many hyphal and basidiospore characters with $A$. infirma and it also causes a brown rot (Davidson et al. 1947, David \& Tortić 1984). So these two species seem to be most closely related to each other. The type of $A$. oleracea was obtained in culture (Davidson et al. 1947) and we are therefore inclined not to place too much reliance on the type. The basidiospores of $A$. oleracea are reported to be oblong or more or less fusoid and often slightly arcuate near the apiculus, $5-7.5(-8) \times 2-3 \mu \mathrm{m}$ in size (Lowe 1966, Gilbertson \& Ryvarden 1986). A. oleracea is also reported to produce chlamydospores (Davidson et al. 1947), which we have not observed in A. infirma. Unlike in A. infirma, some inflated (up to $10 \mu \mathrm{n}$ wide) generative hyphae are present in $A$. oleracea. Deviating opinions are presented in the literature concerning the macroscopical characters of A. oleracea: the basidiocarps are described as perennial by Gilbertson (1981) and Lowe (1966), while Ryvarden \& Johansen (1980) and Gilbertson \& Ryvarden (1986) consider them to be annual. The pores are reported to be $2-4$ per $\mathrm{mm}$ (Lowe 1966) or up to 6-7 per mm (Kotlaba et al. 1984). The subiculum is cork-coloured in African material (Ryvarden \& Johansen 1980), while elsewhere it is reported to be white (e.g. Kotlaba et al. 1984, Gilbertson \& Ryvar- 


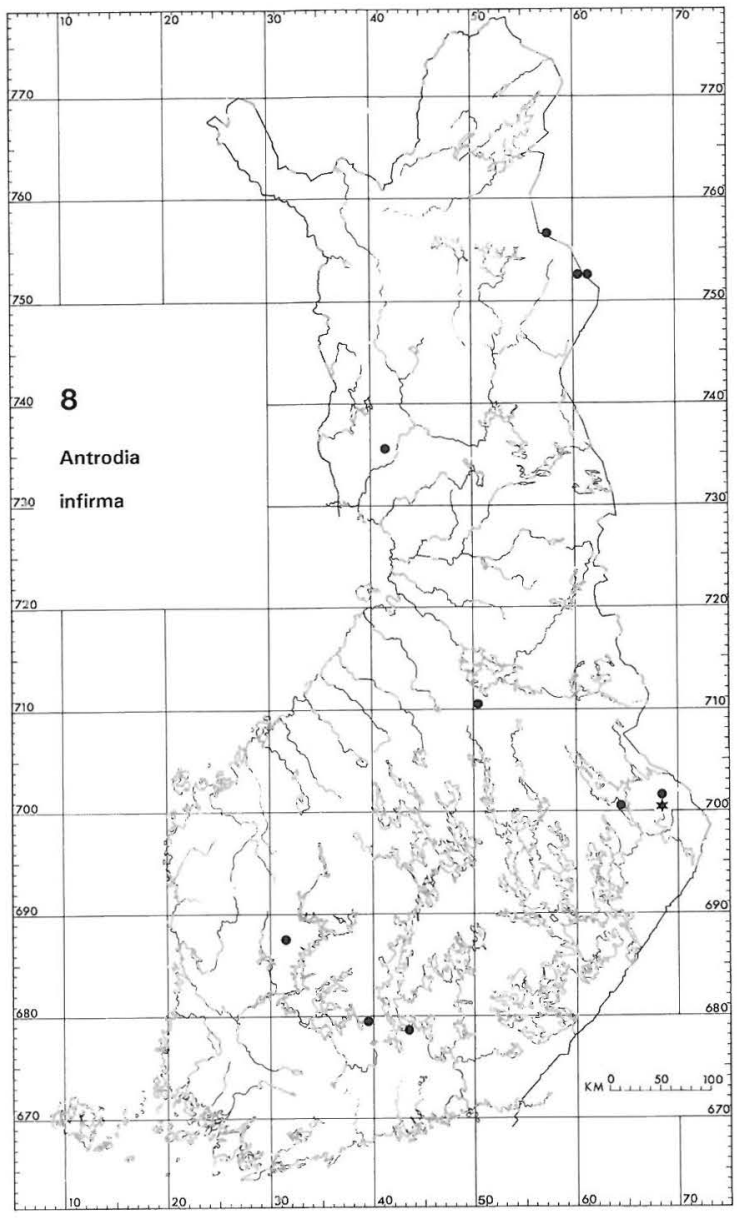

Fig. 8. The distribution of Antrodia infirma Renvall \& Niemelä in Finland according to the material examined. ${ }^{*}=$ The type locality.

den 1986). The basidiocarps of $A$. infirma are definitely annual and its subiculum is white.

The host relationships differ between the two species. Davidson et al. (1947) and Berry and Lombard (1978) have shown that in southern North America Antrodia oleracea is a heart-rot-causing fungus of living and dead oaks (Quercus rubra L. group). In our material $A$. infirma is restricted to conifers, mainly pine, and we therefore consider the host to be a good tool for separating these two polypores. A. oleracea has also been reported on pine, from Cuba (Kotlaba et al. 1984), but we have not seen the specimen.
Antrodia infirma has evidently a different climatic preference from A. oleracea: it is a species of the coniferous zone of Europe, often growing near the alpine and polar timberline, i.e. the Northern Boreal (upper Oroboreal) zone. A. oleracea has never been recorded from Europe, and it is distributed from nemoral (Temperate) to subtropical North America and in tropical Africa (Kotlaba et al. 1984).

To summarize, A. oleracea differs from A. infirma in its basidiospores, which are shorter and sligthly arcuate close to the apiculus, in its shorter and almost pyriform basidioles which are easily separated, e.g. in $\mathrm{CB}$, in its inflated generative hyphae, and in its brittle tubes, smaller pores and different hosts and distribution. In addition, A. oleracea is unchangeable in $\mathrm{KOH}$ (see Lowe 1966), while $A$. infirma has a characteristic oily and messy appearance in $\mathrm{KOH}$.

\section{Notes on the hyphal structures and the generic delimitation of the new species}

The hyphal systems of these species are not easily classified as mono-, di- or trimitic according to the criteria presented by Corner (1953), Gilbertson and Ryvarden (1986) and many others. The vegetative hyphae of both the new species are unevenly distributed and their amount varies greatly in different parts of the basidiocarp. In Antrodia primaeva binding hyphae are present in some restricted areas inside otherwise monomitic context and if a small number of sections are made without true care, the real structure remains unobserved. In $A$. infirma skeletal hyphae are very rare and almost absent from the subiculum, and they often form isolated clusters in the trama (Figs. 6 and $9 \mathrm{~b}$ ). Horizontal sectioning is the surest way of checking their presence and distribution. While examining the species, we made several vertical sections without seeing a single skeletal hypha. Therefore the microscopical examination of these species has to be done systematically and with special care.

Because of the intricate hyphal structures of the new species, their generic placement poses some major problems. If strict attention is paid to the characters of the basidiospores, the hyphal structure and the type of rot, Antrodia primaeva should evidently be placed in Fomitopsis: it is a trimitic, brownrot-causing polypore with inamyloid, indextrinoid, acyanophilous and smooth basidiospores. However, the annual, soft and cheese-like basidiocarps, almost monomitic context with only a few binding hyphae, and dimitic trama are characters which are alien to Fomitopsis as defined, for instance, by Ryvarden (1991). Recently Kotlaba and Pouzar (1990) sepa- 
rated two new genera from that genus: Pilatoporus Kotl. \& Pouz. and Rhodofomes Kotl. \& Pouz. The main criteria for this division were found in the thickness of the basidiospore wall, the characters of the pileal surface, the colour of the context and the perenniality of the basidiocarps. Although we agree with Donk (1974) that Fomitopsis, as currently understood (Gilbertson \& Ryvarden 1986, Bernicchia 1990, Ryvarden 1991), is a heterogeneous entity, we are not ready to adopt the new division. Accordingly we are reluctant to place A. primaeva in Pilatoporus, a genus of strongly trimitic and tough fibrous-corky polypores.

When selecting the genus for Antrodia infirma, our starting point was the type of rot: we consider the species to cause a brown rot, although the kind of decay is not easily seen in old tree trunks, inhabited by many fungi. The weakly dimitic structure guided us to Fibroporia as delimited by Parmasto (1968) and Niemelä (1985b). The type of rot fits that genus and the hyphal characters are basically the same. However, the core species of the genus, $F$. vaillantii (Fr.) Parm. and F. gossypium (Speg.) Parm., have shorter and more truncate basidiospores. Further, a drawback to the choice of Fibroporia is that it has not achieved wide acceptance among mycologists.

The genus Amyloporiella was described (illegitimately, see Ryvarden 1991) by David and Tortić (1984) to replace Amyloporia Bond. \& Sing. (Bondartsev \& Singer 1941, Singer 1944, Bondartsev 1953) in favour of a better type. However, the selection of a neotype for Polyporus calceus (Fr.) Schw. by Ryvarden (1991) settled the meaning of the generic name Amyloporia, and made its redescription as Amyloporiella unnecessary. David and Tortić (1984) merged together some resupinate, brown-rot-causing polypores with a dimitic or subtrimitic hyphal system, variable amyloid reaction in the trama and skeletal hyphae mostly soluble in $10 \% \mathrm{KOH}$ (all included in Antrodia by Gilbertson \& Ryvarden 1986). It is evident that this genus or subgenus is a natural one, the members even having further characters in common (spore shape, conical or fusiform cystidioles, basidia much shorter than in Antrodia, etc.). An accurate delimitation, however, should be worked out. In that connection David and Tortić also included Antrodia oleracea in Amyloporiella. At present, we feel that it fits Antrodia better, where it was placed by Ryvarden (Ryvarden \& Johansen 1980).

For practical reasons the concept of the genus Antrodia has been greatly expanded in most new manuals (Ryvarden 1976, 1991, Gilbertson \& Ryvarden 1986) from the original idea of Donk (1966). This has led to a taxonomically unwelcome situation, where a rela-

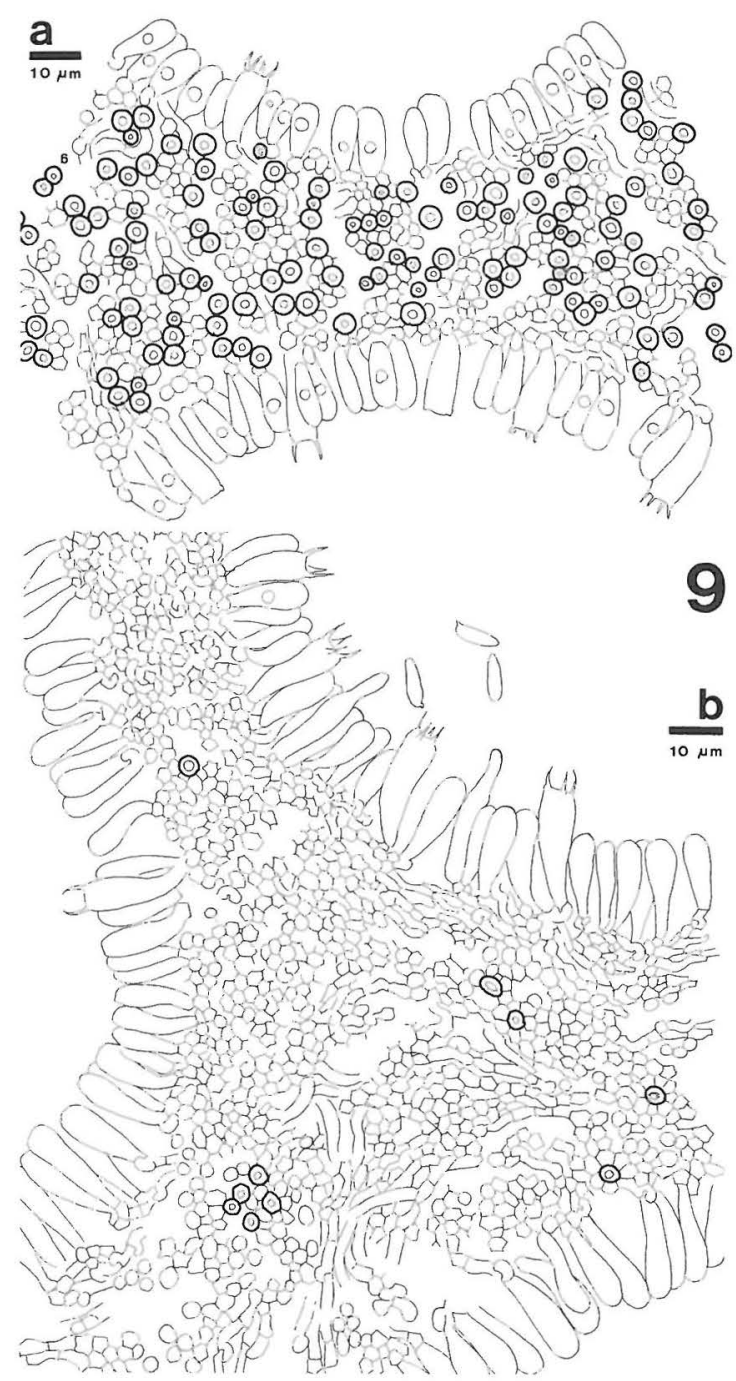

Fig. 9. Horizontal sections of dissepiments showing the distribution of skeletal hyphae in trama: a) Antrodia primaeva Renvall \& Niemelä (Renvall 991, H), b) Antrodia infirma Renvall \& Niemelä (Penttilä 1235, holotype H). Drawn in Cotton Blue.

tively heterogeneous group of poroid fungi are linked for the sake of two key characters, dimiticity and the type of rot (for discussions see, e.g., Donk 1974, Niemelä \& Ryvarden 1975, Niemelä 1978, Ryvarden 1991). Technically, however, the solution is the most practical, while we await a comprehensive revision of brown-rot-causing poroid fungi having more or less dimitic hyphal systems with variable colour reactions 
and smooth, inamyloid, indextrinoid and acyanophilous basidiospores. At present Antrodia includes some almost monomitic species (genus Fibroporia sensu Parmasto 1968 and Niemelä 1985b), slightly trimitic polypores, and species with a strong amyloid reaction in the trama.

We are bound to accept the practical generic delimitations of Antrodia and Fomitopsis and the most appropriate solution was to describe the two new Nordic species in the genus Antrodia. The value of the hyphal system as one of the basic characters in the taxonomy of polypores appears to require some reevaluation. A new, more delicate hyphal type classification may perhaps be needed especially as concerns the ramified generative and vegetative hyphae.

\section{Excluded taxa}

When trying to find older names for the Nordic taxa described in this paper we studied the following type specimens.

\section{Bjerkandera roseomaculata Karst.}

Hedwigia 30:247, 1891 (holotype H).

We agree with Lowe (1956) and Ryvarden (1978) that the type belongs to Postia placenta.

\section{Physisporus albolilacinus Karst.}

Hedwigia 31:293, 1892 (holotype H).

We also place this name in the synonymy of Postia placenta (see Lowe 1956).

\section{Poria carbonicola Karst.}

Finska Vet.-Soc. Öfv. Förh. 46(11):4, 1904 (holotype H, see Lowe 1956).

The type, collected near Lake Baikal, Russia, is sterile and was left undetermined by us. Not Antrodia primaeva, A. infirma, or Dichomitus stenospora.

\section{Poria carnicolor Baxter}

Pap. Michigan Acad. Sci. Arts Lett. 26:109, 1941 ('1940') (holotype MICH).

We consider the type to belong to Postia placenta (see Lowe 1966).

\section{Poria cognata Overh.}

Mycologia 35:248, 1943 (original collection BPI; invalid: lacking a Latin description).
According to Lowe (1966) and Ryvarden \& Gilbertson (1984) this is a synonym of Postia rancida (Oligoporus rancidus). However, the specimen is dimitic with a few skeletal hyphae and in our opinion it belongs to Antrodia oleracea.

\section{Poria gelatinosotubulosa Pilát}

Bull. Soc. Mycol. France 51:383, 1936 (holotype PRM).

Kotlaba and Pouzar (1988) identified the type as a pale form of Postia placenta (Ceriporiopsis placenta (Fr.) Dom.), and it 'is obviously a synonym of Tyromyces placenta' according to Parmasto (1986). Although the specimen is in rather poor condition (partly due to the gelatinous tubes), we agree with them.

\section{Poria microspora Overh.}

in Nobles, Canadian J. Res. 21:224, 1943 (isotype PACMA).

The type belongs to Postia placenta (Poria monticola Murr.), as was also noted by Lowe (1966).

\section{Poria monticola Murr.}

Mycologia 12:90, 1920 (holotype NY).

The variability of Postia placenta was discussed by Domański (1965, 1970a), who concluded that Poria monticola belongs to $P$. placenta. Ryvarden (1985) did not find any spores of the type and his identification was Antrodia sp. Later, however, Gilbertson and Ryvarden (1986) considered P. monticola a synonym of $P$. placenta (Oligoporus placentus). On examination of the type material alone, we could not find any remarkable differences between $P$. placenta and $P$. monticola and we consider them to be a single species.

\section{Poria oleracea Davidson \& Lombard}

Mycologia 39:317, 1947 (holotype BPI, see Ryvarden \& Johansen 1980, David \& Tortic 1984).

The differences between this and A. infirma are discussed in the section 'Notes on Antrodia infirma'.

\section{Poria rancida Bres.}

Fungi Tridentini 2:96, 1900 (holotype S, see Larsen \& Lombard 1986, Ryvarden 1988).

We agree with Larsen and Lombard (1986) that the species belongs to Postia. 


\section{Poria stenospora Overh.}

Proc. Pennsylvania Acad. Sci. 13:125, 1939 (original collection PACMA; invalid: lacking a Latin description).

In our opinion both Overholts (1939) and Lowe (1966) were right in treating this as a separate taxon. The species is undoubtedly a Dichomitus, as stated by Ryvarden and Gilbertson (1984), who placed it in the synonymy of $D$. squalens. Critical characters of the genus are the presence of skeleto-binding hyphae which are distinctly cyanophilous, and the cylindrical shape of the basidiospores. In both the European and American materials of $D$. squalens, however, the basidiospores measure ca. 8-11 × 2.9-3.3 $\mu \mathrm{m}$, while in $P$. stenospora the spores measure ca. (6.8-)7.5-8 $(-9) \times 2-2.1 \mu \mathrm{m}$. The difference in the diameter seems to be especially distinct. $D$. squalens has clavate basidia and basidioles, ca. 15-18 x 7-8 and 13-17 x 6.5-7 $\mu \mathrm{m}$, respectively; $P$. stenospora has oblongsubglobose basidia ca. $12-13 \times 6-6.5 \mu \mathrm{m}$ and pyriform-globose basidioles measuring 10-13 $\times$ 5.5-6 $\mu \mathrm{m}$, i.e. shorter and much more rounded. In $D$. squalens the pores are ca. 3-5 per $\mathrm{mm}$ and in $P$. stenospora 5-8 per mm. $P$. stenospora is resupinate (Lowe 1966); D. squalens tends to grow pilei, whenever possible. Dichomitus albidofuscus (Dom.) Dom. differs from $P$. stenospora, e.g., in having shorter basidiospores (4-6.5 × 2-3 $\mu \mathrm{m}$ ) (Domański 1966, 1972).

For the reasons given above, we accept the taxon as a good species of Dichomitus and propose the following name:

\section{Dichomitus stenospora Renvall \& Niemelä n.sp.}

Dichomitus squalens (Karst.) Reid similis, sed sporis angustioribus (ca. 7-9 $\times 2 \mu \mathrm{m}$ ), basidis et basidiolibus minoris, et poris minoris (6-8 per mm). Holotypus: U.S.A., Washington, Newman Lake, Pseudotsuga menziesii (as taxifolia), 2.VIII. 1936 C.R. Stillinger 3660 (Herb. L.O. Overholts 21564; PACMA 1697). Sub. n. 'Poria stenospora Overholts'.

\section{Trametes alaskana Baxter}

Pap. Michigan Acad. Sci. Arts Lett. 27:150, 1942 ('1941') (holotype MICH).

This species belongs to the complex of species which are variably identified as Antrodia albida (Fr.: Fr.) Donk, A. heteromorpha (Fr.: Fr.) Donk or A. serpens (Fr.: Fr.) Karst. A thorough revision would be very welcome.

\section{Trametes squalens Karst.}

Rabenhorst \& Winter, Fungi Eur. Extraeur. No. 3528 (syntype H, see Lowe 1956).
The specimen has cyanophilous skeleto-binding hyphae. = Dichomitus squalens; see its discussion.

\section{Tyromyces ellisianus Murr.}

North American Flora 9(1):34, 1907 (holotype NY, see Reid 1965, Ryvarden 1988).

A synonym of Dichomitus squalens.

Acknowledgements. Financial support from the Academy of Finland (Project No. 1011799, 1991-1993) is gratefully acknowledged. Heikki Kotiranta (Helsinki) was aware of the existence of Antrodia primaeva as a distinct taxon; we thank him for material and valuable taxonomic discussions. Special thanks are due to Tarja Renvall (Helsinki), who worked together with P.R. in the field and collected specimens of the taxa described above. The curators of various herbaria are thanked for arranging loans of type specimens. Dr. Leif Ryvarden (Oslo) generously sent us reference material of related taxa. We thank Outi Airaksinen, Reijo Penttilä and Reima Saarenoksa (all from Helsinki) who kindly forwarded specimens for our study. Prof. Teuvo Ahti (Helsinki) helped in finding Latin names for the new species; he and Krister Karttunen (Helsinki) prepared the Latin descriptions. Ms. Anna A. Damström, M.A., revised the English of this paper.

\section{References}

Ahti, T., Hämet-Ahti, L. \& Jalas, J. 1968: Vegetation zones and their sections in northwestern Europe. - Ann. Bot. Fennici 5:169-211.

Bernicchia, A. 1990: Polyporaceae s.l. in Italia. - 594 pp. Istituto di Patologia Vegetale, Università degli studi di Bologna, Bologna.

Berry, F.H. \& Lombard, F.F. 1978: Basidiomycetes associated with decay of living oak trees. - U.S. Dep. Agric. For. Res. Pap. NE-126:1-116.

Bondartsev, A. S. 1953: Trutovye griby evropeyskoy chasti SSSR i Kavkaza. - 1106 pp. Akad. Nauk SSSR, Moskva.

Bondartsev, A. S. \& Singer, R. 1941: Zur Systematik der Polyporaceen. - Ann. Mycol. 39:43-65.

Corner, E. 1953: The construction of polypores 1. Introduction: Polyporus sulphureus, P. squamosus, P. betulinus and Polystictus microcyclus. - Phytomorphology 3:152-167.

David, A. \& Tortic, M. 1984: Amyloporiella gen. nov. Trans. British Mycol. Soc. 83:659-667.

Davidson, R.W., Lombard, F.F. \& Hirt, R.R. 1947: Fungi causing decay in wooden boats. - Mycologia 39: 313-327.

Domanski, S. 1965: Grzyby zasiedlajace drewno w Puszczy Białowieskiej 3. Ceriporiopsis placenta (Fr. sensu J. Erikss.) Domanski, jej formy i ich rozpoznanie. - Acta Soc. Bot. Poloniae 34:491-531.

Domałski, S. 1966: Grzyby zasiedlajace drewno w Puszczy Białowieskiej 4. Poria albidofusca, sp. nov. i jej rozpoznanie. - Acta Soc. Bot. Poloniae 35:462-475.

Domanski, S. 1970a: Grzyby zasiedlajace drewno w Puszczy Białowieskiej 9. Dalsze badania nad grzybem Ceriporiopsis 
placenta (Fr. sensu J. Erikss.) Doman. - Acta Soc. Bot. Poloniae 39:51-62.

Domanski, S. 1970b: Grzyby zasiedlajace drewno w Puszczy Białowieskiej 13. Dwa gatunki Diplomitoporus Domań. gen. nov. - Acta Soc. Bot. Poloniae 39:191-207.

Dománski, S. 1972: Fungi: Polyporaceae 1, Mucronoporaceae 1. -235 pp. Foreign Scientific Publications, Warsaw.

Donk, M.A. 1966: Notes on European polypores 1. - Persoonia 4:337-343.

Donk, M.A. 1974: Check list of European polypores. - Verh. Koninkl. Nederlandse Akad. Wetensch. Afd. Natuurk., Tweede Reeks 62:1-469.

Eriksson, J. 1958: Studies in the Heterobasidiomycetes and Homobasidiomycetes - Aphyllophorales of Muddus National Park in North Sweden. - Symb. Bot. Upsalienses 16(1):1-172.

Eriksson, J. \& Strid, A. 1969: Studies in the Aphyllophorales (Basidiomycetes) of northern Finland. - Rep. Kevo Subarctic Res. Sta. 4:112-158.

Gilbertson, R.L. 1981: North American wood-rotting fungi that cause brown rots. - Mycotaxon 12:372-416.

Gilbertson, R.L. \& Ryvarden, L. 1986: North American polypores 1. Abortiporus-Lindtneria. - Pp. 1-433. Fungiflora, Oslo.

Gilbertson, R.L. \& Ryvarden, L. 1987: North American polypores 2. Megasporoporia-Wrightoporia. - Pp. 434-885. Fungiflora, Oslo.

Holmgren, P.K., Holmgren, N.H. \& Barnett, L.C. 1990: Index herbariorum 1. The herbaria of the world. 8th ed. Regnum Vegetabile 120:1-693.

Koski-Kotiranta, S. \& Niemelä, T. 1988 (1987): Hydnaceous fungi of the Hericiaceae, Auriscalpiaceae and Climacodontaceae in northwestern Europe. - Karstenia 27:43-70.

Kotiranta, H. \& Larsson, K.-H. 1990 (1989): New or little collected corticolous fungi from Finland (Aphyllophorales, Basidiomycetes). - Windahlia 18:1-14.

Kotlaba, F, \& Pouzar, Z. 1988: Type studies of polypores described by A. Pilát 1. — Česká Mykol. 42:129-136.

Kotlaba, F. \& Pouzar, Z. 1990: Type studies of polypores described by A. Pilát 3. — Česká Mykol. 44:228-237.

Kotlaba, F., Pouzar, Z. \& Ryvarden, L. 1984: Some polypores, rare or new for Cuba. - Česká Mykol. 38:137-145 + App.: Tables 7-12.

Largent, D., Johnson, D. \& Watling, R. 1977: How to identify mushrooms to genus 3. Microscopic features. - $148 \mathrm{pp}$. Mad River Press, Eureka.

Larsen, M.J. \& Lombard, F.F. 1986: New combinations in the genus Postia Fr. (Polyporaceae). - Mycotaxon 26:271273.

Lowe, J.L. 1956: Type studies of the polypores described by Karsten. - Mycologia 48:99-125.

Lowe, J.L. 1966: Polyporaceae of North America. The genus Poria. - State Univ. Coll. For. Syracuse Univ. Techn. Publ. 90:1-183.

Melo, I. \& Ryvarden, L. 1989: Fomitopsis iberica Melo \& Ryvarden sp. nov. - Bol. Soc. Brot. (Sér. 2) 62:227-230.
Niemelä, T. 1978: On Fennoscandian polypores 6. Antrodia plicata n. sp. - Karstenia 18:43-48.

Niemelä, T. 1985a: On Fennoscandian polypores 9. Gelatoporia n. gen. and Tyromyces canadensis, plus notes on Skeletocutis and Antrodia. - Karstenia 25:21-40.

Niemelä, T. 1985b: Mycoflora of Poste-de-la-Baleine, northern Québec. Polypores and the Hymenochaetales. - Naturaliste Canadien 112:445-472:

Niemelä, T. \& Ryvarden, L. 1975: Studies in the Aphyllophorales of Africa. IV: Antrodia juniperina, new for East Africa. - Trans. British Mycol. Soc. 65:427-432.

Overholts, L.O. 1939: New or little known species of Poria.Proc. Penn. Acad. Sci. 13:121-125.

Parmasto, E. 1968: Conspectus systematis Corticiacearum.261 pp. Acad. Scient. Estonicae, Tartu.

Parmasto, E. 1986: Buchbesprechung. W. Jülich, Die Nichtblätterpilze, Gallertpilze und Bauchpilze...- Nova Hedwigia 42:207-211.

Parmasto, E. \& Parmasto, I. 1987: Variation of basidiospores in the Hymenomycetes and its significance to their taxonomy. - Bibl. Mycol. 115:1-168.

Reid, D.A. 1965: May fungi in Portugal.- Rev. Biol. 5:135-158.

Renvall, P., Renvall, T. \& Niemelä, T. 1991a: Basidiomycetes at the timberline in Lapland 1. Introduction.- Karstenia 31:1-12.

Renvall, P., Renvall, T. \& Niemelä, T. 1991b: Basidiomycetes at the timberline in Lapland 2. An annotated check-list of the polypores of northeastern Finland.- Karstenia 31: 13-28.

Ryvarden, L. 1971: The genera Stereum (s. lato) and Hymenochaete in Norway.- Norwegian J. Bot. 18:97-108.

Ryvarden, L. 1976: The Polyporaceae of North Europe 1. Albatrellus - Incrustoporia.-Pp. 1-214. Fungiflora, Oslo.

Ryvarden, L. 1978: The Polyporaceae of North Europe 2. Inonotus - Tyromyces. - Pp. 215-507. Fungiflora, Oslo.

Ryvarden, L. 1985: Type studies in the Polyporaceae 17. Species described by W.A. Murrill. - Mycotaxon 23:169-198.

Ryvarden, L. 1988: Type studies in the Polyporaceae 20. Species described by G. Bresadola. - Mycotaxon 33: 303-327.

Ryvarden, L. 1991: Genera of polypores. Nomenclature and taxonomy. - Synopsis Fungorum 5:1-363.

Ryvarden, L. \& Gilbertson, R.L. 1984: Type studies in the Polyporaceae 15. Species described by L.O. Overholts, either alone or with J.L. Lowe. - Mycotaxon 19:137-144.

Ryvarden, L. \& Johansen, I. 1980: A preliminary polypore flora of East Africa. - $636 \mathrm{pp}$. Fungiflora, Oslo.

Singer, R. 1944: Notes on taxonomy and nomenclature of the polypores. - Mycologia 36:65-69.

Received on 8 November 1991 